\title{
KARAKTERISTIK PERTUMBUHAN DAN PERKEMBANGAN BALITA YANG TIDAK MENDAPATKAN ASI EKSKLUSIF PADA USIA 24 BULAN DI WILAYAH KERJA PUSKESMAS MABELOPURA PALU 2016
}

\author{
Nita Damayanti ${ }^{*}$, I Gede Ade Sanjaya $^{1}$ \\ ${ }^{1}$ Program Studi Pendidikan Dokter, Fakultas Kedokteran Universitas Alkhairat, Jl. Diponegoro No. 39 \\ Palu 94221, Sulawesi Tengah, Indonesia \\ *Corresponding author: Telp: +62811451689 email: nita.unisa@ gmail.com
}

\begin{abstract}
ABSTRAK
Ganguan perkembangaan dapat berakibat menimbulkan keterlambatan pertumbuhan dan perkembangan kedepan bagi seorang anak. Tujuan penelitian ini adalah untuk mengetahui karakteristik pertumbuhan dan perkembangan balita yang tidak mendapatkan asi eksklusif di wilayah kerja puskesmas Mabelopura palu 2016. Metode penelitian menggunakan desain yang bersifat observasional dengan pendekatan Cross sectional yang dimulai pada bulan Agustus 2015 sampai Januari 2016 di wilayah kerja puskesmas Mabelopura palu. Populasi Penelitian adalah seluruh balita di wilayah kerja Puskesmas Mabelopura (Palu Selatan). Analisis data menggunakan metode frequenzi dengan metode alternatif yang diolah menggunakan perangkat lunak SPSS versi 17. Hasil penelitian diperoleh jumlah bayi yang tidak diberi asi eksklusif usia 6 bulan yaitu sebanyak 96 balita, balita gizi kurang 45,82\% sedangkan gizi baik 15,65\%, gizi buruk 31,25\%, balita pendek 48,96\% lebih banyak dari pada normal 33,31\% dan sangat pendek $17,73 \%$, ukuran kepala normal balita 60,38\%. Berdasarkan kemampuan motorik kasar, perkembangan meragukan $46,85 \%$ lebih banyak dari pada perkembangan yang sesuai yaitu $21,91 \%$ dan menyimpang $31,24 \%$. Berdasarkan kemampuan motorik halus perkembangan meragukan 54,14\% lebih banyak dari pada perkembangan sesuai yaitu $28,16 \%$ dan menyimpang $17,70 \%$. Berdasarkan kemampuan bahasa, perkembangan sesuai 43,73\%, meragukan yaitu 27,11\% dan menyimpang 29,16\%. Berdasarkan kemampuan personal sosial perkembangan sesuai 52,50\%, meragukan 33,20\% dan yang menyimpang 14,30\%. Simpulan, dari 96 balita yang tidak diberi asi eksklusif usia 6 bulan pada pertumbuhan dan perkembangannnya termasuk dalam kategori normal.
\end{abstract}

Kata Kunci : pertumbuhan balita, perkembangan balita, asi non eksklusif

\begin{abstract}
Developmental disorders can result in delays in growth and future development for a child. The purpose of this study was to determine the growth and development characteristics of toddlers who did not get exclusive breastfeeding in the working area of Mabelopura health center hammer 2016. The research method used an observational design with a cross sectional approach which began in August 2015 to January 2016 in the working area of Mabelopura hammer health center. The study population was all toddlers in the work area of the Mabelopura Health Center (South Palu). Data analysis used the frequenzi method with an alternative method which was processed using SPSS version 17 software. The results showed that the number of infants who were not exclusively breastfed 6 months of age were 96 toddlers, under five toddlers were $45.82 \%$ while good nutrition was $15.65 \%$, 31.25\% malnutrition, short toddlers $48.96 \%$ more than normal $33.31 \%$ and very short $17.73 \%$, normal toddler head size $60.38 \%$. Based on gross motor skills, the development doubted $46.85 \%$ more than the corresponding development ie $21.91 \%$ and deviated $31.24 \%$. Based on fine motoric abilities the development doubted $54.14 \%$ more than the corresponding development ie $28.16 \%$ and deviated $17.70 \%$. Based on language skills, development corresponds to $43.73 \%$, doubting that is $27.11 \%$ and deviating $29.16 \%$. Based on personal development social capabilities according to $52.50 \%$, doubting $33.20 \%$ and deviating $14.30 \%$. Conclusion, out of 96 toddlers who were not exclusively breastfed, the age of 6 months in their growth and development was included in the normal category.
\end{abstract}

Keywords: toddler growth, toddler development, non-exclusive breastfeeding 


\section{PENDAHULUAN}

ASI eksklusif adalah pemberian air susu ibu kepada bayi dari usia 0 sampai dengan 6 bulan tanpa diberikan makanan atau minuman tambahan selain obat untuk terapi pengobatan penyakit (WHO, 2008). Pemberian ASI dapat mencukupi semua kebutuhan tumbuh kembang anak secara lengkap. Tidak hanya untuk menambah berat badan tetapi juga memberi gizi kepada otak, menstimulasi otak yang otomatis mencukupi kebutuhan perkembangan ketrampilan, kecerdasan, mental, emosi dan sosial anak. Bagaimana pemberian nutrisi pada 3 tahun pertama kehidupan anak ini secara tidak langsung akan menentukan keberhasilan anak saat dewasa nanti. ASI memenuhi semua kebutuhan asuh, asih, asah anak. Tidak hanya signifikan pada kenaikan berat badan akan tetapi juga meningkatkan integritas dan kredibilitas anak sejak dini. ${ }^{1}$ Kolostrum mengandung zat kekebalan 10-17 kali lebih banyak dari susu matang. Zat kekebalan tubuh yang ada pada ASI dapat melindungi bayi dari penyakit diare dan menurunkan kemungkinan bayi terkena penyakit infeksi telinga, batuk, pilek, dan penyakit alergi (Kementrian Kesehatan RI, 2014). Bayi di bawah usia 2 bulan yang tidak disusui adalah enam kali lebih mungkin untuk meninggal akibat diare atau infeksi saluran pernapasan akut dari pada mereka yang disusui. Sekitar 1,3 juta kematian dapat dicegah setiap tahun jika tingkat pemberian ASI eksklusif meningkat menjadi $90 \%$. $^{2}$

Pada tahun 2013 pemberian ASI eksklusif di Indonesia sebesar $54,3 \%$ belum mencapai target $75 \%$ hanya Provinsi Nusa Tenggara barat yang mencapai target yaitu 79,7\%, Jakarta 67,1\%, di Sulawesi Tengah 62,3\%. Prevalensi pemberian ASI eksklusif di Indonesia mengalami penurunan dari tahun ke tahun yaitu dari 40,2\% (1997) menjadi 39,5\% (2003) dan semakin menurun pada tahun 2007 yaitu sebanyak 32\% (Data Survei Demografi dan Kesehatan Indonesia (1997-2007). Turun menjadi 15,3\% pada Tahun 2010 (laporan Riskesdas Tahun 2010). Di Puskesmas Mabelopura Kecamatan Palu Selatan dari 1.482 balita yang mendapat ASI eksklusif 584 balita sedangkan yang tidak mendapatkan ASI eksklusif 898 balita (data puskesmas mabelopura 2013). Di puskesmas birubuli dari 1.392 balita yang mendapatkan ASI eksklusif 861 balita, sedangkan yang tidak mendapatkan ASI eksklusif 531 balita (data puskesmas birobuli 2013).
Prevalensi gizi kurang di Indonesia pada balita (BB/U) tahun 2013 yaitu 19,6\%, di DKI Jakarta 14\%, dan Sulawesi Tengah 24,1 dan prevalensi kurus dan sangat kurus pada balita (BB/TB) di Indonesia tahun 2013 adalah 12,1\%, di DKI Jakarta 9,9\%, di Slawesi Tengah 9,4\%. Kasus gizi buruk Sulawesi Tengah (Sulteng) sampai November 2015 di 13 kabupaten dan kota yaitu 445 kasus dimana di Kota Palu dan Donggala sebanyak 146 kasus, Kabupaten Sigi 35 kasus, Parigi Mautong 81 kasus, Poso 47 kasus, Tojo Una Una 5 kasus, Morowali 5 kasus Banggai 14 kasus, Banggai Kepulauan 8 kasus, Toli toli 57 kasus, Buol 21 kasus, Banggai Laut 10 kasus, Morowali Utara 6 kasus. ${ }^{5}$

Penelitian yang dilakukan oleh Budiwan Putri Edining Tyas pada tahun 2012, terdapat hubungan yang signifikan antara pemberian ASI eksklusif dan ASI Non eksklusif dengan pertumbuhan berat badan pada bayi 0-6 bulan di Desa Giripurwo, Wonogiri. ${ }^{7}$ Penelitian lain yang dilakukan Retty Anisa Damayanti pada tahun 2016, balita dengan riwayat mendapatkan ASI non eksklusif memiliki risiko stunting 16,5 kali lebih besar dibandingkan balita dengan riwayat mendapatkan ASI eksklusif. ${ }^{6}$ Penelitian lain juga dilakukan Lony Novita pada tahun 2007, dimana hasil penelitian menunjukkan pemberian ASI noneksklusif berpeluang bayi mempunyai IQ di bawah rata-rata sebesar1,68 kali lebih besar dibandingkan di atas rata-rata. Dari aspek fungsi kognitif pemberian ASI eksklusif memberikan hasil lebih baik dibandingkan dengan yang tidak mendapat ASI eksklusif. ${ }^{8}$

Berdasarkan penelitian-penelitian tersebut telah menjadi bukti bahwa sangat perlu diperhatikan ganguan tumbuh kembang pada balita di Indonesia khususnya di Sulawesi Tengah. Oleh karena itu dilakukan penelitian tentang karakteristik pertumbuhan dan perkembangan balita yang tidak mendapatkan ASI eksklusif di wilayah kerja Puskesmas Mabelopura Palu.

\section{METODOLOGI}

Desain penelitian yang digunakan adalah penelitian yang bersifat observasional dengan pendekatan Cross sectional. Penelitian ini dilakukan pada tanggal 20 Agustus 2015 sampai dengan 28 Januari 2016 di wilayah kerja Puskesmas Mabelopura (Palu Selatan). Populasi penelitian ini adalah seluruh balita di wilayah kerja Puskesmas Mabelopura. Subyek penelitian adalah balita terpilih di wilayah kerja Puskesmas 
Mabelopura. Kriteria Inklusi adalah balita yang berada di wilayah kerja Puskesmas Mabelopura (Palu Selatan), bayi Laki-laki dan perempuan, bayi berusia 3 bulan sampai 5 tahun, bayi yang diizinkan oleh orang tuanya ikut penelitian tanpa paksaan (orang tua merupakan penduduk Kota Palu). Kriteria ekslusi adalah balita yang menderita penyakit infeksi lain, balita mempunyai kelainan pada saluran cerna, ibu/responden tidak bisa berkomunikasi. Data antara lain: usia, jenis kelamin, berat badan, panjang badan, lingkar kepala, kemampuan motorik kasar, motorik halus, personal sosial dan bahasa. Data yang diperoleh diolah dengan menggunakan SPSS 17.

\section{HASIL DAN PEMBAHASAN}

HASIL

Pada penelitian ini diteliti karakteristik pertumbuhan dengan mendeskripsikan data berat badan, panjang badan dan lingkar kepala berdasarkan umur pada balita yang tidak mendapatakan ASI eksklusif.

Tabel 1. Karakteristik berat badan menurut umur 24 Bulan

\begin{tabular}{|c|c|c|}
\hline Variabel & $\mathrm{N}$ & $\%$ \\
\hline $\begin{array}{c}\text { Berat badan/Umur } \\
\text { 1. Gizi buruk }\end{array}$ & 30 & $31,25 \%$ \\
\hline 2.Gizi Kurang & 44 & $45,82 \%$ \\
\hline 3.Gizi Baik & 15 & $15,64 \%$ \\
\hline 4.Gizi lebih & 7 & $7,29 \%$ \\
\hline Total & 96 & $100 \%$ \\
\hline
\end{tabular}

Tabel 1 menunjukan data subjek dengan balita gizi kurang lebih banyak dibandingkan gizi buruk dan gizi baik 15,65 \%. Gizi lebih 7,29\%.

Tabel 2. Karakteristik panjang badan menurut umur 24 Bulan

\begin{tabular}{|c|c|c|}
\hline Variabel & $\mathrm{N}$ & $\%$ \\
\hline $\begin{array}{c}\text { Tinggi badan/Umur } \\
\text { 1.Tinggi }\end{array}$ & 17 & 17,73 \\
\hline 2.Pendek & 47 & 48,96 \\
\hline 3.Normal & 32 & 33,31 \\
\hline Total & 96 & $100 \%$ \\
\hline
\end{tabular}

Tabel 2 menunjukan data subjek berdasarkan tinggi badan menurut umur bahwa balita yang pendek 48,96 lebih banyak dari pada sangat pendek 17,73 dan normal 33,31.
Tabel 3. Karakteristik Lingkar kepala menurut umur 24 Bulan

\begin{tabular}{|c|c|c|}
\hline Variabel & $\mathrm{N}$ & $\%$ \\
\hline $\begin{array}{c}\text { Lingkar kepala/Umur } \\
\text { 1.Mikrocefali }\end{array}$ & 36 & 37,48 \\
\hline 2.Normal & 58 & 60,38 \\
\hline 3.Makrocefali & 2 & 2,14 \\
\hline Total & 96 & $100 \%$ \\
\hline
\end{tabular}

Tabel 3 menunjukan data subjek bahwa balita yang mempunyai ukuran kepala normal lebih banyak dari pada mikrosefal dan makrosefal.

Tabel 4. Karakteristik perkembangan motorik kasar

\begin{tabular}{|c|c|c|}
\hline Variabel & $\mathrm{N}$ & $\%$ \\
\hline $\begin{array}{c}\text { Motorik Kasar } \\
\text { 1. Sesuai }\end{array}$ & 21 & 21,91 \\
\hline 2.Meragukan & 45 & 46,85 \\
\hline 3.Penyimpangan & 30 & 31,24 \\
\hline Total & 96 & $100 \%$ \\
\hline
\end{tabular}

Tabel 4 menunjukan data subjek bahwa balita yang mempunyai perkembangan yang meragukan 46,85\% lebih banyak dari pada perkembangan yang menyimpang $31,24 \%$ dan yang sesuai yaitu $21,91 \%$.

Tabel 5. Karakteristik perkembangan motorik halus

\begin{tabular}{|c|c|c|}
\hline Variabel & $\mathrm{N}$ & $\%$ \\
\hline $\begin{array}{c}\text { Motorik Halus } \\
\text { 1. Sesuai }\end{array}$ & 27 & 28,16 \\
\hline 2.Meragukan & 52 & 54,14 \\
\hline 3.Penyimpangan & 17 & 17,70 \\
\hline Total & 96 & $100 \%$ \\
\hline
\end{tabular}

Tabel 5 menunjukan data subjek bahwa balita yang mempunyai perkembangan yang meragukan 54,14\% lebih banyak dari pada perkembangan yang seseuai yaitu $28,16 \%$ dan yang menyimpang $17,70 \%$.

Tabel 6. Karakteristik perkembangan bahasa

\begin{tabular}{|l|c|c|}
\hline \multicolumn{1}{|c|}{ Variabel } & $\mathrm{N}$ & $\%$ \\
\hline $\begin{array}{l}\text { Bahasa } \\
\text { 1. Sesuai }\end{array}$ & 42 & 43,73 \\
\hline 2.Meragukan & 26 & 27,11 \\
\hline 3.Penyimpangan & 28 & 29,16 \\
\hline Total & 96 & $100 \%$ \\
\hline
\end{tabular}

Tabel 6 menunjukan data subjek bahwa balita yang mempunyai perkembangan yang sesuai 
43,73\% lebih banyak dari pada perkembangan yang meragukan yaitu $27,11 \%$ dan yang menyimpang $29,16 \%$.

Tabel 7. Karakteristik perkembangan personal sosial

\begin{tabular}{|c|c|c|}
\hline Variabel & $\mathrm{N}$ & $\%$ \\
\hline $\begin{array}{c}\text { Personal Sosial } \\
\text { 1. Sesuai }\end{array}$ & 50 & 52,50 \\
\hline 2.Meragukan & 32 & 33,20 \\
\hline 3.Penyimpangan & 14 & 14,30 \\
\hline Total & 96 & $100 \%$ \\
\hline
\end{tabular}

Tabel 7 menunjukan data subjek sosial bahwa balita yang mempunyai perkembangan yang sesuai $52,50 \%$ lebih banyak dari pada perkembangan yang meragukan yaitu 33,20\% dan yang menyimpang $14,30 \%$ pada balita yang tidak mendaptkan ASI diwilyah kerja Puskesmas Mabelopura Palu.

\section{PEMBAHASAN}

\section{Karakteristik Pertumbuhan}

Pada penelitian ini, rata-rata pertumbuhan berat badan bayi yang tidak diberikan asi eksklusif adalah gizi kurang $45,82 \%$ dan gizi buruk dengan jumlah $31,25 \%$ dibandingkan dengan gizi baik $15,65 \%$. Dan gizi lebih $7,29 \%$ selama tahun pertama. Pertumbuhan terjadi sangat cepat terutama selama 6 bulan pertama. Bayi memperoleh pertambahan berat badan 150 sampai 210 gram (5 sampai 7 ons) setiap minggu sampai sekitar usia 5 sampai 6 bulan. Berat badan rata-rata bayi usia 6 bulan adalah dua kali lipat dari berat badan lahir, sekitar 7260 gram. Bayi yang mendapatkan asi sampai lebih dari usia 4 sampai 6 bulan secara khas lebih ringan dari bayi yang mendapatkan susu botol. Hasil penelitian ini sejalan dengan penelitian yang dikemukakan oleh american academy of pediatrics, 1998; dewey dkk (1993 dalam wong 2008) yang menyatakan bahwa "bayi yang mendapatkan asi sampai lebih dari usia 4 sampai 6 bulan secara khas lebih ringan dari bayi yang mendapatkan Susu botol". Berat badan bayi yang mendapatkan asi lebih ringan dibandingkan dengan berat badan bayi yang mendapatkan pasi namun jika dilihat dari kurva KMS, bayi yang mendapatkan asi memiliki berat badan dalam rentang berat badan normal, sedangkan bayi yang mendapatkan pasi memiliki berat badan berada pada rentang obesitas dikarenakan kandungan protein pada susu formula sekitar 3 kali lebih banyak dibanding asi, kandungan lemak pada asi cenderung lebih mudah dicerna dan diserap oleh bayi dibandingkan dengan lemak pada susu formula. Hal ini dikarenakan kandungan kalori dalam asi diserap oleh tubuh bayi sesuai dengan kebutuhan yang dibutuhkan oleh bayi. Namun tubuh bayi akan menyerap semua kalori yang terdapat pada pasi. Sehingga, bayi yang mendapatkan asi eksklusif lebih ringan dibandingkan dengan pasi.

Pada pertumbuhan tinggi badan bayi yang diberikan asi eksklusif adalah pendek 48,96 lebih banyak dari pada tinggi badan normal 33,31. Panjang badan pada bayi yang diberikan PASI adalah 17,071 $\mathrm{cm}$ dengan standar deviasi 3,9763. Rata-rata panjang badan bayi yang mendapatkan ASI eksklusif lebih pendek dibandingkan dengan bayi yang mendapatkan PASI. Panjang badan pada bayi akan bertambah $2,5 \mathrm{~cm}$ (1 inci) setiap bulan selama 6 bulan pertama dan kemudian melambat selama 6 bulan kedua. Pertambahan panjang melonjak dengan cepat, bukan dengan pola lambat dan bertahap. Tinggi rata-rata adalah $65 \mathrm{~cm}$ pada usia 6 bulan. Panjang badan pada bayi yang mendapatkan ASI cenderung lebih lambat dibandingkan dengan PASI, namun panjang badan pada bayi yang mendapatkan ASI sesuai dengan berat badan bayi. Bayi yang mendapatkan ASI memiliki berat badan lebih ideal, artinya panjang badan sesuai dengan berat badan bayi, bayi memiliki berat badan dan panjang badan yang proporsional. Pada bayi yang mendapatkan PASI, bayi cenderung terlihat "bongsor", antara berat badan dan panjang badan tidak sesuai dengan usianya. Hal ini dikarenakan ASI merupakan larutan kompleks yang mengandung karbohidrat, lemak, dan protein.

Karbohidrat utama dalam ASI adalah laktosa. Di dalam usus halus laktosa akan dipecah menjadi glukosa dan galaktosa oleh enzim laktase. Produksi enzim laktase pada usus halus bayi kadang-kadang belum mencukupi, untungnya laktase terdapat dalam ASI. Sebagian laktosa akan masuk ke usus besar, dimana laktosa ini akan difermentasi oleh flora usus (bakteri baik pada usus) yaitu laktobasili. Bakteri ini akan menciptakan keadaan asam dalam usus yang akan menekan pertumbuhan kuman patogen (kuman yang menyebabkan penyakit) pada usus dan meningkatkan absorpsi (penyerapan) kalsium dan fosfor. ASI hanya menyerap kalsium dan fosfor sesuai dengan kebutuhan bayi sedangkan PASI tidak. 
Pada pertumbuhan lingkar kepala bayi yang diberikan asi eksklusif adalah ukuran kepala normal $60,38 \%$ lebih banyak dari pada mikrosefal 37,48\%. Pertumbuhan lingkar kepala bayi berjalan sangat cepat selama 6 bulan pertama, lingkar kepala bertambah setiap bulannya sekitar $1,5 \mathrm{~cm}$. Ukuran rata-rata adalah $43 \mathrm{~cm}$ pada usia 6 bulan. Pertambahan ukuran kepala mencerminkan pertumbuhan dan diferensiasi sistem saraf. Pertambahan yang relatif konstan juga dapat diketahui dari proporsi besar kepala dengan panjang badan. Saat lahir, kepala berukuran seperempat bagian dari panjang badan dan setelah dewasa, besar kepala hanya seperdelapan dari panjang badan. Oleh karena itu, lingkar kepala ini hanya efektif pada 6 bulan pertama sampai umur 2-3 tahun, kecuali pada keadaan tertentu seperti bentuk kepala yang besar pada anak yang menderita hydrocephalus. Pada dua tahun pertama ini, pertumbuhan otak relatif pesat. Pengukuran lingkar kepala dimaksudkan untuk menaksir pertumbuhan otak. Berat otak waktu lahir adalah sekitar 350 gram, pada usia 1 tahun beratnya hampir mencapai 3 kali lipat yaitu 925 gram $75 \%$, dan mencapai $90 \%$ pada usia 6 tahun. Pertumbuhan ukuran lingkar kepala umumnya mengikuti pertumbuhan otak sehingga bila ada hambatan atau gangguan pada pertumbuhan lingkar kepala, pertumbuhan otak biasanya juga terhambat. Komposisi yang terdapat dalam ASI juga sudah lengkap, di dalamnya terkandung AA dan DHA yang telah digembar-gemborkan produsen susu formula untuk meningkatkan kecerdasan anak. Hal ini perlu diketahui Ibu sebelum hamil, sehingga Ibu lebih siap untuk memberikan ASI eksklusif. Bayi yang mendapatkan ASI eksklusif telah terbiasa untuk belajar sejak dini, berbagai panca indranya telah distimulasi sejak dini. Menurut Yen (dalam Chomaria 2011), bayi yang diberikan ASI eksklusif akan terstimulasi dari segi penciuman, penglihatan, pengecapan, pendengaran dan sentuhan. Bayi setelah dilahirkan dan diletakkan di dada Ibu, secara spontan akan menggunakan indra pengecap dan penciumannya untuk menelusuri cairan sejenis yang dikeluarkan dari putting ibu. Selain itu dalam waktu 9 menit, bayi baru lahir mampu menoleh dengan mata mengikuti rangsangan yang bergerak. Saat berada didada, bayi akan mendengar lebih jelas suara ibu dan detak jantung ibu seperti dalam kandungan. Kontak kulit antara Ibu dan bayi dapat memberikan rasa nyaman dan tenang pada bayi. Semua ini menyebabkan IQ dan EQ bayi yang mendapatkan ASI eksklusif lebih tinggi dibandingkan dengan PASI, karena sejak detikdetik awal kelahirannya di dunia, baik fisik maupun psikis terstimulasi secara optimal.

Penelitian tentang perbedaan IQ bayi yang mendapatkan ASI eksklusif dan PASI telah dilakukan. Berdasarkan hasil penelitian di Denmark, diketahui bahwa bayi yang diberi ASI hingga lebih dari sembilan bulan akan tumbuh cerdas. Hal tersebut disebabkan ASI mengandung AA dan DHA, sementara bayi yang tidak diberi ASI mempunyai IQ yang lebih rendah $7-8$ poin dibandingkan dengan bayi yang diberikan ASI eksklusif.

\section{Karakteristik Perkembangan}

Berdasarkan penelitian, kebanyakan balita mempunyai perkembangan motorik kasar yang meragukan $46,85 \%$ lebih banyak dari pada perkembangan yang seseuai yaitu $21,91 \%$ dan yang menyimpang $31,24 \%$ pada balita yang tidak mendaptkan ASI.

Otak balita lebih terbuka untuk proses pembelajaran dan pengayaan. Sisi negatifnya, otak balita lebih peka terhadap lingkungan, utamanya lingkungan yang tidak mendukung seperti asupan gizi yang tidak adekuat, kurang stimulasi dan tidak mendapat pelayanan kesehatan yang memadai. Masa lima tahun pertama kehidupan merupakan masa yang sangat peka terhadap lingkungan dan masa ini berlangsung sangat pendek sertatidak dapat diulang lagi, makamasa balita disebut sebagai "masakeemasan" (golden period), "jendela kesempatan" (window ofopportunity) dan "masa kritis"(critical period) Oleh karena itu pemberian ASI sedini mungkin segera setelah bayilahir sangatlah penting karena ini merupakan stimulasi dini terhadap tumbuh kembang anak.

Pada tingkat perkembangan motorik kasar balita ditemukan 21 balita yang berkembang sesuai umur dan 52 balita yang tidak berkembang sesuai umur, hampir setengah dari balita dapat melaksanakan perintah Peneliti sesuai dengan DENVER, namun balita yang perkembangan motorik kasarnya tidak sesuai umur bukan berarti tidak bisa melakukan apaapa,tetapi anak tetap dapat melakukan seperti anak yang lain hanya sedikit terlambat, atau dengan kata lain anak tersebut belum mencapaiper kembangan motorik kasar sesuai dengan umurnya. Berdasarkan DENVER, salah satu contoh anak usia 11 bulan sudah dapat berdiri sendiri, sedang kananak tersebut diatas 
yang mempunyai perkembangan motorik kasar tidak sesuai umurnya dapat berdiri tetapi dengan bantuan. Hal ini kemungkinan disebabkan oleh kurangnya stimulasi dari keluarga, kurangnya informasi dalam mendidik anak dalam membantu perkembangan anak ataupun dikarenakan pekerjaan orang tua sehingga perhatian dan didikan kepada anak sangatlah kurang.

Berdasarkan perkembangan motorik halus, yang meragukan 54,14\% lebih banyak dari pada perkembangan yang seseuai yaitu $28,16 \%$ dan yang menyimpang $17,70 \%$. Letak perbedaan perkembangan motorik halus yang motorik halus akan berpengaruh pada pertumbuhan dan perkembangan anak. Anak yang memiliki motorik halus yang normal maka dalam melakukan suatu pekerjaan pekerjaan atau instruksi yang disuruh akan lebih cepat mengerjakannya dibandingkan anak yang memiliki motorik halus yang abnormal membutuhkan waktu yang lebih lama atau sama sekali tidak dapat menyelesaikan pekerjaan atau instruksi yang disuruh. Motorik halus adalah gerakan yang menggunakan otot-otot halus atau sebagian anggota tubuh tertentu, yang ASI eksklusif misalnya pada bayi ASI Eksklusif umur 5 bulan sudah mampu memfokuskan arah pandangannya pada suatu benda yang kecil yang ada diatas kepalanya (benang), Sedangkan pada bayi non ASI Eksklusif belom mampu memfokuskan pandangannya pada suatu benda kecil. Hasil penelitian ini sejalan dengan bukti ilmiah terbaru yang dikeluarkan oleh Jurnal Paediatrics pada tahun 2006, terungkap data bahwa bayi yang diberisusu formula memiliki kemungkinan untuk meninggal dunia pada bulan pertama kelahirannya. Peluang itu 25 kali lebih tinggi dari bayi yang disusui oleh ibunya secara eksklusif. dipengaruhi oleh kesempatan untuk belajar dan berlatih. Keterampilan motorik halus melibatkan gerakan yang diatur secara halus. Gangguan pada perkembangan motorik halus biasanya menyebabkan anak-anak mengalami kesulitan belajar. Adapun perkembangan motorik halus pada masa prasekolah, yaitu mulai memiliki kemampuan menggoyangkan jarijari kaki, menggambar dua atau tiga bagian, memilih garis yang lebih panjang dan menggambar orang, melepas objek dengan jari lurus, mampu menjepit benda, melambaikan tangan, menggunakan tangannya untuk bermain, menempatkan objek kedalam wadah, makan sendiri, minum dari cangkir dengan bantuan, menggunakan sendok dengan bantuan, makan dengan jari, serta membuat coretan di atas kertas.

Berdasarkan penelitian, kebanyakan balita mempunyai perkembangan yang sesuai $43,73 \%$ lebih banyak dari pada perkembangan yang meragukan yaitu $27,11 \%$ dan yang menyimpang $29,16 \%$.

Pada penelitian ini perkembangan bahasa yang seusai dengan usia lebih banyak hal ini terjadi karan faktor stimulasi dimana dapat diketahui faktor stimulasi mempengaruhi pertumbuhan dan perkembangan pada balita sebanyak 23 responden $(82,1 \%)$. Stimulasi merupakan bagian dari kebutuhan dasar anak yaitu asah atau kegiatan merangsang kemampuan dasar anak umur 0-6 tahun agar anak tumbuh dan berkembang optimal. Setiap anak perlu mendapat stimulasi rutin sedini mungkin dan terus menerus pada setiap kesempatan. Dengan memberikan stimulasi yang berulang dan terus menerus pada setiap aspek perkembangan anak berarti telah memberikan kesempatan pada anak untuk tumbuh dan berkembang secara optimal. Dapat diartikan bahwa stimulasi mempengaruhi dalam pertumbuhan dan perkembangan balita. Dalam setiap ada kesempatan berinteraksi dengan balita maupun melakukan aktivitas orang tua harus memberikan stimulasi secara terus menerus dan bervariasi kepada balita yang disesuaikan dengan usia perkembangan dan kemampuan balita.Sehingga semakin sering kitra memberikan stimulasi dengan mengajak anak berbicara sehingga kemampuan terbentuknya kosakata atau bahasa lebih cepat tergantung dari jenis stimulasi yang diberikan

Didapatkan kesimpulan bahwa kebanyakan balita mempunyai perkembangan yang sesuai $52,50 \%$ lebih banyak dari pada perkembangan yang meragukan yaitu 33,20\% dan yang menyimpang $14,30 \%$. Perkembangan anak selalu mengikuti pola yang teratur dan berurutan, tahap-tahap tersebut tidak bisa terjadi terbalik, misalnya anak lebih dahulu mampu berdiri sebelum berjalan, perkembangan berlangsung dari tahapan umum ke tahapan spesifikan terjadi berkesinambungan.

Jika setiap kelainan/penyimpangan sekecil apapun apabila tidak dideteksi apalagi tidak ditangani dengan baik, akan mengurangi kualitas sumber daya manusia dikemudian hari. Oleh karena itu perkembangan anak sangatlah perlu diperhatikan, baik secara fisik maupunpsikologis, semua ini dimulai sejak 
proses tumbuh dan kembang pada usia dini, terutama pada saat masa balita, hal ini bertujuan untuk membentuk kualitas SDM yang optimal dalam membangun bangsa kedepan. Salah satu upaya dalam membentuk perkembangan yang optimal sedini mungkin sangatlah tergantung pada pemberian ASI/menyusui, karena ASI tidak hanya berfungsi dalam memberikan nutrisi bagi bayi, tetapi juga sangat mempunyai arti dalam perkembangan anak karena seolah-olah hubungan anak ibu tidak terpurtus begitu dia dilahirkan ke dunia.

\section{DAFTAR PUSTAKA}

1. Aimi-asi. 2010. Pengaruh ASI Terhadap Tumbuh Kembang Anak. Diunduh tanggal 23 agustus 2015 dari : http://aimiasi.org/pengaruh-asi-terhadap-tumbuhkembang-anak/

2. Alive \& Thrive. Exclusive breastfeeding. Diunduhtanggal 4 mei 2014 dari: http://www.aliveandthrive.org/ourfocusareas/exclusive. 3Apr201401:07:27 GMT

3. Depkes. 2001. Strategi Nasional Peningkatan Pemberian ASI 01-205 Jakarta : Departemen Kesehatan RI.

4. Depkes RI. 2005. Tumbuh Kembang Anak . Jakarta : Departemen Kesehatan RI.

5. Depkes RI. Profil Sulteng. Diunduh tanggal 6 september 2013 dari: www.depkes.go.id/downloads/profil/sulteng0 7.pdf

6. Damayanti Retty Anisa, Muniroh Lailatul, Farapti. 2016. Perbedaan Tingkat Kecukupan Zat Gizi dan Riwayat Pemberian ASI Eksklusif pada Balita Stunting dan Non Stunting. Program Studi S1 Ilmu Gizi. Fakultas Kesehatan Masyarakat. Universitas Airlangga. Surabaya. Media Gizi Indonesia. 11(1): 61-69

7. Edining Tyas, Budiwan P, Widodo Pratikto, Anang Ganda. 2013. Hubungan antara Pemberian ASI Eksklusif dan ASI Non Eksklusif dengan Pertumbuhan Berat Badan Bayi 0-6 bulan di Desa Giripurwo, Wonogiri. Fakultas Kedokteran Universitas Muhammadiyah Surakarta.

8. Novita Lony, Gurnida Dida A, Garna Herry. 2008. Perbandingan Fungsi Kognitif Bayi Usia 6 Bulan yang Mendapat dan yang Tidak Mendapat ASI Eksklus. Bagian Ilmu Kesehatan Anak Fakultas Kedokteran
Universitas Padjadjaran. Rumah Sakit Dr. Hasan Sadikin Bandung. Sari Pediatri. 9(6). 